\title{
Nineteenth Century New Zealand Novels and Novellas Published as Serials in New Zealand, Australian and British Newspapers and Periodicals and Never Published as Monographs: A Checklist
}

\author{
J.E. TRAUE
}

Additions, corrections and comments are invited. Please send details to jim.traue@gmail.com

"It is to the old newspapers that we must go if we want to see the beginning of colonial fiction ... there are in the dusty files of these and other journals many stories of colonial life which have never struggled out of the papers into book form." Clara Eyre Cheeseman, "Colonials in Fiction," NZ Illustrated Magazine 7 no. 4 (1 January 1903): 274.

A New Zealand novel is defined as one first published in New Zealand, or with a significant reference to New Zealand or written by an author resident in New Zealand. Where a serial carries the byline "Written specially for," "Specially written for" or "Written expressly for" it is assumed that the author is resident locally within New Zealand unless there is evidence to the contrary. In general, fictional works appearing in three or fewer episodes are excluded. Fiction written for children is not included.

Airlie, pseud. Author of short stories published in the Saturday Advertiser in September 1879 and New Zealand Mail, 1895-97. Identified as “a young lady,” NZ Mail, 5 June 1880.

Esther. A New Zealand Story. By Airlie.

(Short romance set in Wellington

and southern New Zealand)

\section{A. M. See Pyke, Vincent}

\section{A. M. K. See Kavanagh, Arthur McMurrough}

A. M. M. See M, A. M.

Alice, pseud. See Baker, Louisa Alice

Alien, pseud. See Baker, Louisa Alice

\section{Anon 1}

Allan Hurst. A Tale of the Diggings.

\section{Anon 2}

Brownebrook. A Story of Colonial Life.

("Brownebrook," near "Tilton" in Otago)
New Zealand Mail, 12 Jun-10 Jly 1880

(5 instalments)
Otago Witness, 6-27 Sep 1873

(4 instalments)

Otago Witness, 22 Aug 1874-27 Feb 1875 


\section{Anon 3}

The Brown's First Ball. A Colonial Sketch. Written Specially for the "Southern Mercury." (set in London)

\section{Anon 4}

Christine. An Original Tale. Specially Written for the Southern Mercury (set in New Zealand)

\section{Anon 5}

Kiorana. A Tale of the Maori War.
Southern Mercury, 2 Dec 1876-13 Jan 1877

Southern Mercury, 25 Aug-15 Sep 1877 (4 instalments)

\section{Anon 6}

A Message for Miss Darrell. Specially Written for "The Observer."

Oxford Observer, 30 Nov 1889-1 Feb 1890

\section{Anon 7}

Mrs Leyburn's Story. As Told by My Wife.

Wanganui Chronicle, 19 Dec 1861-16 Jan 1862

Anon 8 "By a local author."

Nellie Fanshaw. A Tale of the Yorkshire Dales. Yeoman (Wanganui) 20 Aug-5 Nov 1881 (Postscript, 5 Nov. "Harry Fanshaw ... He loved his adopted country and he thought his duty lay there. His wife was born in New Zealand and did not care for England.")

Anon 9 Author of "The Rise and Progress of Sandylands" [set in Melbourne 1839], written expressly for the Penny Journal by the author of "Only Colonial," published in 5 brief instalments in the Penny Journal, 25 May -29 Jun 1867. Possibly W. H. J Seffern, a partner in the Penny Journal, and formerly a journalist in Australia.

Only Colonial. Written Expressly for the Penny

Penny Journal, 9 Feb-4 May1867

Journal. (account of woman's life in Liverpool and then in Sydney, 1839-1851)

Anon 10 "By a local author."

Philo Maori. A Story of Colonial Life. 


\section{Anon 11}

A Romance of Lake Wakatipu. A Legend of the Lakes.

\section{Anon 12}

Sleeper Awakened. A Canterbury Tale.

Founded on Facts.

Atha, pseud. See Westbury, Frank Atha

Aunt Peg, pseud.

Strangers Yet.

("by a local writer" Starts London,

leaving for NZ)

The Sick Stockman.

Nurse Fulton's Romance, or Ups

And Downs of a Colonial Girl's Life
Otago Witness, 2 Jun-4 Aug 1892

Star (Christchurch) 16-30 Apr 1884

(10 instalments)
Oxford Observer, 24 Aug-21 Sep 1889

(5 instalments)

Oxford Observer, 16 Nov-14 Dec 1889

(4 instalments)

Oxford Observer, 12 Dec 1891-16 Jan 1892

(4 instalments)

Baker, Louisa Alice (Dawson), 1858-1926. "Dot" of Dot's Little Folk, and editor of the Ladies Page of the Otago Witness, 1886-1894. Left for England 1894 and under the pseudonym Alien had 16 novels and one book of short stories issued by British and U.S. publishers 1894-1920. Also published short stories for children, some serialized, in Our Little Folks page, under Alice.

Chalk. By Alice.

Otago Witness, 16 Jly 1886-11 Mar 1887

(In the section headed "The Ladies")

Fickle Jack, or From Weakness to Strength By Alice. (In the section headed "The Ladies."

Otago Witness, 1 Apr-9 Sep 1887

Set in Christchurch)

A Child of the Pakehas. By Alien.

Otago Witness, 25 Aug-29 Sep 1898 Now First published.

Bakewell, Robert Hall, 1831-1908. English-born doctor, resident Hokitika 1880-82.

The Mulatto Marquis. By Thomas F. Haslam Specially Written for this Journal.
West Coast Times, 13 Mar-26 May 1880.

"To be continued."

Bell, Fabian, pseud. See Cotton, Francis Edwina

Bell, Gordon, pseud. "Gordon Bell ... a lady who resides less than a thousand miles from Milton” (Bruce Herald, 8 Sep 1891, 4). 
A Veritable Cain.

Bruce Herald, 7-21 March 1893

(5 instalments).

Bourke, Emma Mary, 1854-1924, and John Bourke, 1849-1891. E. M Bourke, author of Little History of New Zealand (1881), was a prolific author of short stories, poems and historical articles, some under her married name of Mrs E. M. Dunlop.

Supplejack. A Story of New Zealand.

Leader (Melbourne) 23 Je-15 Dec 1883

(Set in Coromandel, Grahamstown,

Havelock, Nelson. Includes Maungatapu

murders)

Bracken, Thomas, 1843-1898.

Golden Foundations.

Saturday Advertiser (Dunedin), 5 Apr-19 Jly 1879

C. M. W. See W., C. M.

Campbell, John Logan, 1817-1912.

My Visit to Waiwera-Baden, and Things

That I Have Seen and Heard and Thought

NZ Herald, 1 Mar-5Apr 1879

in Passing Through the World.

(4 instalments)

Carrick, Henderson, 1823-1886. Born Ireland, to NZ c.1871, Dunedin bookseller. Contributed short stories to the Otago Witness.

True Nobility.

Otago Witness, 6 Jly-16 Nov 1878

\section{Carter, William}

The Greenstone Image.

New Zealand Mail, 22 Jun-6 Jly 1899

Cheeseman, Clara, 1852-1943. Her 3 volume novel, A Rolling Stone, was published by Richard Bentley in 1886.

In the Olden Time.

Saturday Advertiser, (£20 prize story)

20 Dec 1879-24 Jan 1880

Estranged for Life.

Sydney Mail, 17 Jan-1 May 1880

Under Suspicion.

NZ Public Opinion and Saturday Advertiser, $1 \mathrm{Jly}-5$ Aug 1882

Had He Known. A Story of New

Cassell's Family Magazine, v.18, 1891/2,

Zealand Gold Thirst

pp. 45-54, 106-115, 152-163, 236-246 
Citizen of Dunedin, pseud. Possibly John Moore Perrier, the editor of the Bruce Herald, or J. J. Utting.

Kate Fraser.

Bruce Herald, 3-24 Nov 1874

(7 instalments)

Colclough, Mary Ann (Barnes), 1836-1885. Regular contributor to newspapers in the Auckland province, 1860s-1872, under the pen name Polly Plum. Left for Australia 1872.

The Half-Caste Wife. By the author of Alone in the World (Part of Alone in the World, set in Auckland and written by "a lady" was published in the Weekly Argus (Auckland) in 1865 and published as a 56p. monograph by Mitchell and Seffern, Auckland, 1866. The Weekly Argus was an offshoot of the New Zealander which "lived just a year" (Scholefield). No copies have survived)

Effie’s Inheritance. By Polly Plum.
Possibly Australian newspaper before 1866, or more likely the Weekly Argus (Auckland)

\section{Coo-ee, pseud. See Walker, William Sylvester}

Cottle, Thomas,1845-1923. Author of Frank Melton's Luck (Auckland, Brett, 1891), short stories and poems.

The Old Fence Dog.

Weekly Standard, 21 Apr-19 May 1894 (5 instalments)

Cotton, Francis Edwina (Burbury), 1846-1919. Formerly of Akaroa; private school in Roslyn, Dunedin, 1880s to 1896; teacher of painting, 1896-1901; journalist, 1903-1919. Editor, "A Girl's Page" in Zealandia, 1889-1890.

As Fabian Bell had short stories, travel pieces, and serialized novels published in the Otago Witness, 1877-1919. Also published in New Zealand Illustrated Magazine, Zealandia, Akaroa Mail, Bruce Herald. According to Dear Dot (Otago Witness, 7 Sept 1899) also published in a number of papers in England.

(Writing under the pseudonym)

\section{Fabian Bell}


Stella. A Tale of Two Hemispheres.

After Long Years. A Colonial Story.

Broken Fettters.

Alice. A New Zealand Pastorale in Five Chapters.

An Error of Judgement.

A Letter in Cypher. A Tale of a Secret Society.

Flotsam and Jetsam. A Colonial Story.

The House in the Fells, or His Brother's Keeper.

He and She.

The Price of a Life.
Otago Witness, 3 Mar-1 Dec 1877

Otago Witness, 8 Mar-21 Je 1879

Otago Witness, 5 Jul-13 Sep 1879

Otago Witness, 20 Sept-18 Oct 1879

(5 instalments)

NZ Public Opinion and Saturday Advertiser, 12 Feb-26 Feb 1881

Otago Witness, 30 Dec 1882-9 Jun 1883.

Reprinted in Manchester Evening Mail, 189596; Exeter and Plymouth Gazette, 1897; Blackburn Standard, 1898; Lincolnshire Echo, 1900

Otago Witness, 25 Jun-13 Aug 1886

Otago Witness, 9 May-14 Nov 1889

Otago Witness, 30 Jun-15 Sept 1892

First published Manchester Courier, 1895;

Manchester Times, 1895; Hampshire Telegraph, 1895-96; Portsmouth Evening News, 1895-96; Hartlepool Mail,1895-96. Reprinted Otago Witness, 23 Jan-21 May 1896. Reprinted Lincolnshire Echo, 1897; Staffordshire Sentinel, 1897. Also published in Bendigo Advertiser, Nov 1895-Mar 1896. Barrier Miner Mar-Jun 1896

Otago Daily Times, 3 Apr-11 Sept 1897

(before 1896)

The Hero of the Arawa.

Cowper, Henry,1848-1933. Born in Brazil of British parents, lived in Australia and New Zealand from 1868.

Hinemoa. An Original New Zealand Romance. Goulburn Herald, 22 May-4 Sep 1891;

By Henare te Kaupa.

Hay Standard and Advertiser, 29 May-16 Sep 1891

\section{Craw Linn, pseud. See Flint, Frederick Lindsay Crawford}




\section{Dalton, David}

A Varied Life.

(set in Bristol, San Francisco, Melbourne,

Weekly Standard, 17 Feb-7 Apr 1894

Ballart, Dunedin, Canterbury)

De Condé, pseud. See Joseph, Francis Antonio

Dickson, William Hay, 1849?-1904. Short stories, poems published in the Saturday Advertiser, Temperance Herald. Accountant in Australia, Dunedin 1879, Westport 1883, died in Australia.

Bitter Fruit.

(set in Dunedin)
Clutha Leader, 18 Jun-23 Jul 1880

(6 instalments)

Egan-Lee, Richard, 1808-1879. Born in England, Resident in Tasmania, 1854, Melbourne 1866, Auckland and Napier, 1867, then Melbourne.

The Secret of Whitmore Chase. A Tale of England and Australia. By R. E. Lee.

Hawkes Bay Weekly Times, 29 Jly?-23 Dec? 1867

\section{E.M.T. See T, E. M.}

Eona, pseud. See Finniswood, Emma.

Evans, Charlotte (Lees), 1841-1882. Four novels published as monographs by English publishers, 1874-1903, and serials published in the Family Herald (London).

Guy Eversley.

North Otago Times, 19 Oct 1865-18 Jan 1866

Fancy Free, pseud. Author of several short stories in the Northern Advocate, 1878, including "A New Chum's Experiences in New Zealand.” Possibly a retired Indian Army officer.

Three Comrades. By Fancy Free. Specially

Northern Advocate, 27 Aug-15 Oct 1898

Written for the Northern Advocate. (7 instalments)

(set in India and South-East Asia)

Farjeon, Benjamin Leopold, 1838-1903. First novel in book form, Grif, published by William Hay, Dunedin, 1866. Left Dunedin in 1867 and became popular and prolific novelist in London. Many of his books were later serialized in Australia, Britain and New Zealand.

Life and Adventures of Christopher

Congleton [published anonymously].

\section{Finniswood, Emma}

The Scarecrow. By Eona. (partly set in NZ)
Otago Witness, 17 May 1862-29 May 1863

(unfinished)
Ladies Treasury; A Household Magazine

(London), Jan-Nov 1879 
Flint, Frederick Lindsay Crawford. Alleged remittance man, journalist, mostly resident in Dunedin.

No Country. By Craw Linn.

That Girl. By Craw Linn.
NZ Saturday Advertiser.16 Jun-4 Aug 1877

Observer and Free Lance, 22 Jan?-July1887?

Fookes, Arthur Beckwith Robertson, 1850?-1908.

In the Flesh and the Spirit. A Novel.

Decree Nisi.

H.

Lal.

Our Picnic.
First published in several UK newspapers in 1886, including the Yorkshire Weekly Post, South Durham Herald, Hampshire Telegraph and Weekly Echo and Times. Reprinted New Zealand Mail 13 May-15 Jly 1887

Auckland Star, 12 May-4 Aug 1888

Oxford Observer, 28 Sep-19 Oct 1889

(4 instalments)

Oxford Observer, 1 Feb?-22 Feb 1890

(4 instalments)

Half-Caste Wife, author of The. See Colclough, Mary Ann

\section{Hall, Hickory}

The Virginny Lily. A Romance of Land

Saturday Advertiser, 18 May-15 Jun 1878

And Sea.

Cola de Blanca. Or Tom Hope's Luck.

Saturday Advertiser, Aug 17-21 Sep 1878

Harris, Jane Elizabeth, 1852/3?-1942.

Moanataiari Gold, or Lucy Bentley's Lover. Thames Star, 1-22 July 1882

By Jenny Wren.

(4 instalments)

Haslam, Thomas F., pseud. See Bakewell, Robert Hall, 1831-1908.

\section{Henare Te Kaupa. See Cowper, Henry}

Hudson, Ellen, 1854-1907. “A local author.” Stories published in Otago Witness, Thames Star, and Weekly News.

The Goldies of Golden Terrace.

Australia. Specially written for the Witness.
Otago Witness, 11 Jun-10 Sep 1881

Otago Witness, 18 Mar-17 Jun 1882 
His Good Angel.

Otago Witness, 14 Jul-18 Aug 1883

(6 instalments)

Jenny Wren, pseud. See Harris, Jane Elizabeth

Joseph, Francis Antonio, d.1904. Journalist, editor Clutha Free Press.

Fred's Revenge. By De Condé.

Specially written for the Southern Mercury.

Southern Mercury, 28 Apr-12 May

(set in England)

1876

(3 instalments)

Louis Vernon. By F. A. J. De Condé.

Otago Witness, 16 Feb-29 Jun 1878.

Reprinted Tuapeka Times, 1885

\section{K., A. M. See Kavanagh, Arthur McMurrough}

Kavanagh, Arthur McMurrough, 1851-1926.

The Owner of Langsey Villa. By A. M. K. $\quad$ Nelson Mail, 21 Aug-1 Sep 1897

Kinnear, W. F.

(5 instalments)

The Fortunes of Belmont. A Tale of

New Zealand.

North Otago Standard, 12 Aug-11 Nov 1876

Lapham, Charles Henry, 1847?-1887. Author of the "Spare Hours" column in the Otago Witness. Contributor of stories for children as "Uncle Harry" in "Our Little Folks" in the Otago Witness.

Buck Jones's Training. A Story in Otago Witness, 23 Nov 1878-11 Jan 1879

Sixteen Chapters. By Henry Lapham.

(set in Otago goldfields)

Laura, pseud. See Suisted, Laura Jane (Eyre).

Lee, R. E. See Egan-Lee, Richard

\section{Linn, Craw. See Flint, Frederick Lindsay Crawford}

Lockhart, James. An "Australasian writer." Short stories published in Australian Journal and Australasian Sketcher set in Australia and New Zealand.

Jack Fortune.

(starts and ends in Wales, just over half set in NZ.)

Rough and Smooth.
Australian Journal, Jan-Apr 1872

(4 instalments)

Literary News (Melbourne), 29 Mar-19 Jul 1883 (unfinished) 
Loughnan, Robert Andrew, 1841-1934. Journalist, Lyttelton Times, Catholic Times.

A Singular Legacy.

M, A. See Pyke, Vincent

M, A. M. "a New Zealand authoress"

Edith. By A. M. M.

(A romance, set in Melbourne)
Star (Christchurch), 17 Nov 1886-17 Mar 1887

Otago Witness, 3 Jly 1880-8 Jan 1881

McAlley, Catherine Margherita Marie (Norberg), 1864?- 1949. The author of the serialized novel "Constance" is identified in the Wanganui Herald (31 Dec 1890, 2) as Mrs McCorby of Marton, which was her stage name.

Constance. By Mrs J. McAlley.

(Mostly set in Scotland)

Wanganui Herald, 4 Jan-8 Mar 1890

\section{McCorby, Mrs. See McAlley, Catherine}

McDougall, John William, 1849-1933. Journalist, editor, Hawkes Bay Herald, Daily

Telegraph.

Mr Richard Bede. A Story of New

Zealand.

"To be published in book form in

London and Melbourne" (NZ Herald,

10 June 1893)
Hawkes Bay Herald 26 Nov 1892-

22 Apr 1893

Mansfield, Ernest Richard, 1862-1924. Short stories published in the Wanganui Herald and Star (Christchurch), 1889-91. Ralph Raymond, a novel set mostly in New Zealand, published by Stanley Paul, London, 1913.

Two Chums.

Yeoman (Wanganui), 22 Nov-27 Dec 1890

(New Zealand setting)

Meander, Mrs. Editor of the Ladies Page, Canterbury Times, and a frequent contributor of stories, often serialized in three episodes, in the Star (Christchurch).

Lord Naseby's Nephew. A New Zealand

Story.

Miller, John Augustus, 1833-1903.

A Colonial Maiden. A Story of

Lake Wakatipu. By Sagitta.

The Dream on Ruby Island. A Romance of Lake Wanaka. A New Zealand Story of Fact and Fiction. By Sagitta.
Star (Christchurch), 23 -29 May 1885 (5 instalments)

Otago Witness, 16 Aug 1884-31 Jan 1885

Weekly Times (Invercargill) 7Apr-27 Oct 1893 
Momus, pseud. "A local author."

Lights and Shadows. A Tale by Momus.

North Otago Times, 11 Apr-4 Aug 1871

N. Z., pseud.

Bluebird's Chamber. Written for the Otago

Witness. By N. Z.

Otago Witness, 8 Oct-19 Nov 1891

(set in England)

P., G. M.

Richard Wentworth's Revenge. A Tale in

Three Parts. Written for the Weekly News by

G. M. P.

Weekly News, 12 Aug-9 Sep 1871

(5 instalments)

(set in Germany)

Patrick, Charles. "A local author."

Arcadia in Futuris.

Wanganui Herald, 19 Feb-29 May 1889

(utopian story set in 2004)

(9 instalments)

Polly Plum, see Colclough, Mary Ann (Barnes)

Pyke, Vincent, 1827-1894.

Eustace Egremont. By M. A.

("Contemporary reference suggests

that there was another novel, Eustace

Sydney Mail, 13 Sep-1 Nov 1879. Reprinted

Egremont, which cannot now be traced,"

Saturday Advertiser (Dunedin), 1 May-31 Jly

Oxford Companion to NZ Literature)

Randle, Marie (Dawkins), 1856-1947. Short stories in the Otago Witness; prolific poet under pseudonym Wych Elm.

She's But a Lassie. Written for the Witness

Otago Witness, 13 Apr-10 Aug 1888

Ladies Page by Wych Elm.

Rattray, Lizzie Frost (Fenton), 1855-1931. Social editor, New Zealand Graphic, NZ correspondent for The Gentlewoman. Short stories published under Mrs Rattray, Mrs W.

Rattray, Mrs William Rattray, Mrs L. Frost Rattray in New Zealand Family Friend, NZ Graphic, Waikato Times, Observer. Entry in DNZB, v2, 405-06.

Evelyn Mossley's Lover. A sketch.

Waikato Times, 17 -31 Aug 1889

By Mrs Rattray.

(3 instalments)

("a short original tale," Waikato Times,

17 August 1889. NZ setting)

Bristondell, or An Unlucky Marriage.

Waikato Times, 28 Dec 1889-5 Apr 1890 
(NZ setting)

Camella, or An Ignorant Wrangler.

Waikato Times, 20 Jan-2 Jun 1891

(NZ setting)

Ruha. A Tale of Adventure in the Maori War.

Cassell's Family Magazine, v.19, 1892/3, pp. 527-34, 577-84, 686-93

Sagitta, pseud. See Miller, John A.

San Dolores, pseud. Stories published in the Nelson Mail and the Australasian.

Collins Street East. By San Dolores.

Southern Mercury, 3-24 Jan 1874.

Ohinepuiawhea. A Tale of New Zealand.

Southern Mercury, 17 Sep 1875-6 Jan 1877

By San Dolores.

(irregular, not in every issue)

Suisted, Laura Jane (Eyre) 1840-1903. Entry in DNZB, v.2, pp. 489-90. Author of several short stories published in the Saturday Advertiser and the Canterbury Times under the pseudonym L. J. $\mathrm{S}$ or Mrs James Suisted. Stories also serialized in Swedish periodicals. An Auckland newspaper in 1895 claimed that Tillotson's Fiction Bureau had purchased one of her stories. A story by "Mrs James Suisted"appeared in the 1895 Christmas number of The Lady (London, 1885-).

The Trevors. By Laura.

Saturday Advertiser (Dunedin) 13 Mar3 Apr 1880

Melton Chase. By Laura.

New Zealand Public Opinion, 7-28 Aug

(set in England) 1880

Storm and Calm. Written for the Saturday

Saturday Advertiser, 9 Dec 1882-13 Feb Advertiser by L. J. S. 1883.

(Starts Rome, then London)

T., E. M. Author of other stories in the Southern Mercury.

The Miser's Daughter. By E. M. T. Written

for the Southern Mercury.

(set in Yorkshire)

Christine. An Original Tale. Written for the Southern Mercury by E. M. T.
Southern Mercury, 12 May-16 Jun 1877 (6 instalments)

Southern Mercury, Aug 25-Sep 151877 (4 instalments)

Talbot, Francis Ellen, 1851-1923 (writing as Thorpe Talbot). Joint contributor with Vincent Pyke to White Hood and Blue Cap (Dunedin: Joseph Braithwaite, 1881), author of The New Guide to the Lakes and Hot springs, 1882, the novel Philiberta (Ward Locke, 1883), first published in the Leader (Melbourne) 1882, and the long poem "Guinevere in the South."

An Oasis.

Star (Christchurch), 24-29 Dec 1880

(4 instalments) 
Too Hard a Battle.

All a Mistake.
NZ Public Opinion and Saturday Advertiser, 22 Apr-13 May 1882

NZ Public Opinion and Saturday Advertiser, 30 Sep-4 Nov 1882

Taylor, Emily Matilda, 1853?-1934. Arrived in Auckland 1865; ran a girls' school in Auckland.

Mystery of Wynne Court. Written for the Observer and Free Lance.

(set in England).

Foes in the Family.

(set in England)

Te Kaupa, Henare. See Cowper, Henry

Thatcher, Richmond, 1842-1891.

Black upon Yellow. A Tale. Written

Expressly for the "Saturday Advertiser."
Observer, 11 Apr-26 Sep 1885. "To be continued"

Observer, 28 Nov 1885-8 May 1886. "To be continued"

Utting, John James, 1842-1925. Journalist, in NZ 1865-1881, working on the Otago Guardian, and later the Christchurch Press in the 1870s, later a playwright in Australia.

Frank Calvary. A Semi-nautical novel.

NZ Saturday Advertiser, 14 Oct 1876-16 Jun 1877. Republished Newcastle Morning Herald, 1885

The Golden Cross.

Saturday Advertiser (Dunedin) 13 Sep 1879-

(Set in England, with passing references

to New Zealand)

15 May 1880. Republished Newcastle

Morning Herald, 1884-1885

W., C. M. Author of stories and poems in a wide range of New Zealand newspapers.

Saved From the Flood. A Tale of the Wakatipu. Goldfields. By C. M. W.
NZ Public Opinion and Saturday Advertiser, 11 Sep-9 Oct 1880

(5 instalments)

Walker, William Sylvester, 1846-1926. Born in Australia, educated Oxford (UK), nephew of Rolf Boldrewood. Author of Zealandia's Guerdon (London: John Long, 1902), a collection of episodes relating to New Zealand. Lived in New Zealand, editor Marlborough Press.

Shadowed. By Coo-ee.

Hidden Treasure. By Coo-ee. Or, A Daughter's Revenge.
Observer and Free Lance, 19 Jan-9 Feb 1889 (4 instalments)

Observer and Free Lance, 23 Feb-30 Mar 1899 (6 instalments) 
Webster, Scott. Short stories published in Weekly Press, 1880s-1890s. Resident of Bulls.

Lowes. A Novel.

(Lowes, a small village in

Weekly Press (Christchurch), 24 Jan-23 May

the North Island. Matawai Station,

Wellington settings)

Westbury, Frank Atha, 1838-1901. Popular and prolific Australian author. Served in New Zealand in the $68^{\text {th }}$ Regiment of Foot, 1863-66. Widely serialised in Australia and New Zealand newspapers. Fernbrook's Double: a Romance of Maoriland, published in the Tuapeka Times Supplement in 1892 and in several Australian papers 1884-86 was republished as The Shadow of Hilton Fernbrook by Chatto and Windus in 1896. As Atha, contributed short stories and poems to the Tuapeka Times Supplement and other New Zealand newspapers.

Gainst Wind and Tide.

Maoriland Ho. Nature's Enchanting

Wonder Isle. A Weird and Enchanting

Romance.

Expiation of Claude Wingate. An Australian

Romance.

(Set mostly in Taranaki in 1860s)

The Prodigal of Glencourt. A Romance Of Maoriland.
Once a Week (Melbourne), 12 Nov 1877-11 Feb 1888.

Tuapeka Times Supplement, 23 Sep 1893-27 Jan 1894. Also published in the Camperdown Chronicle and the Riverina Recorder, 1893

Australian Journal, Aug 1899-Jan 1900
Camperdown Chronicle, 6 Jly-12 Oct 1901. Also serialized in at least 4 other Australian newspapers, 1901

Wych EIm, pseud. See Randle, Marie

ACKNOWLEDGEMENTS. To Papers Past, without which this project would have been too laborious to contemplate. To Rowan Gibbs, for generously sharing so much of the information on New Zealand fiction that he has accumulated over the years. To supportive librarians, particularly Linda Te Au of Information Services at the Invercargill Public Library who confirmed the details of one novel in the Invercargill Weekly Times, to the librarians at the Alexander Turnbull Library (especially Fiona Gray) and Victoria University Library who chased elusive references through the electronic databases, and the staff of the Turnbull and Auckland Public Library who hauled so many dusty old volumes out of their basements. 